\title{
Sanitation control of some equipments used in poultry slaughterhouse line
}

\section{Kanatlı kesim hattında kullanılan bazı alet ve ekipmanlarda sanitasyon ișleminin kontrolü}

\author{
Nilgün ÇETiNKAYA ${ }^{1}$, Gökhan Kürşad iNCiLíi ${ }^{1}$, Ali ARSLAN1
}

\section{ABSTRACT}

Objective: Microbial contamination of chicken meat varies depending on various processes applied during production, slaughtering and processing. This study was carried out to investigate the effectiveness of sanitation (cleaning+disinfection) implemented in a commercial poultry slaughterhouse in Elazığ.

Methods: For this purpose, swab samples from defeathering machine fingers, outlet band of water cooling tank, outlet band of air cooling and end product band of diet department were taken to analyze the number of total mesophilic aerobic bacteria (TMAB), coliforms, Enterobacteriaceae and the prevalence of Salmonella spp. before sanitation and at the 20 and 30 minutes after sanitation process.

Results: Total mesophilic aerobic bacteria numbers of the samples taken from fingers of mechanical defeathering machine before sanitation and at the 30 minutes after sanitation process were $5.69 \pm 0.83$, and $4.64 \pm 0.83 \log 10 \mathrm{cfu} / \mathrm{cm} 2$, and the differences between before and after sanitation were significant $(p<0.05)$. In addition, it was determined that the differences of the total mesophilic aerobic bacterica counts between before and after sanitation in the water cooling

\section{ÖZET}

Amaç: Tavuk etinin mikrobiyal kontaminasyonu üretim, ișleme ve kesimhane așamalarına bağlı olarak değișiklik göstermektedir. Bu çalıșma, Elazığ'da bulunan ticari bir kanatlı kesimhanesinde uygulanan sanitasyon (temizlik+dezenfeksiyon) ișleminin etkinliğini incelemek amacıyla yapıldı.

Yöntem: Bu amaçla mekanik tüy yolma makinesi parmakları, su soğutma tankı çıkış bandı, hava soğutma çıkış bandı ve diyet bölümü son ürün dizme bandında sanitasyon öncesi, sanitasyon sonrası 20 . ve 30. dakikalarda swap örnekleri alınarak toplam mezofilik aerob bakteri, koliform grubu bakteri ve Enterobacteriaceae sayıları ile Salmonella spp. prevalansı yönünden araștırıldı.

Bulgular: Sanitasyon öncesi ile sanitasyon sonrası 30. dakikalarda toplam mezofilik aerob bakteri sayılarının tüy yolma parmağında sırasıyla; 5,69 $\pm 0,83$, ve $4,64 \pm 0,83 \log 10 \mathrm{kob} / \mathrm{cm}^{2}$ olduğu ve sanitasyon öncesi ile sonrası arasındaki farkın önemli olduğu tespit edilmiștir $(p<0,05)$. Ayrıca, toplam mezofilik aerobik bakteri sayılarının su soğutma çıkış bandında, hava soğutma çıkış bandında ve diyet bölümü son ürün bandında sanitasyon öncesi ile sonrası arasındaki

${ }^{1}$ Firat University, Faculty of Veterinary Medicine, Department of Food Hygiene and Technology

İletişim / Corresponding Author : Gökhan Kürşad INCCiLi

Fırat Üni., Veteriner Fakültesi, Besin Hijyeni ve Teknolojisi Bölümü 23100 Elazığ - Türkiye E-posta / E-mail : gkincili@firat.edu.tr

DOI ID : 10.5505/TurkHijyen.2019.93275

Çetinkaya N, İncili GK, Arslan A. Sanitation control of some equipments used in poultry slaughterhouse line Turk Hij Den Biyol Derg, 2020; 77(3): 301-310 
outlet band, air cooling outlet band and the diet product final product band were significant $(p<0.05)$. Enterobacteriaceae numbers of the samples taken from fingers of mechanical defeathering machine before sanitation and the 20 and 30 minutes after sanitation process were $4.00 \pm 2.09,2.43 \pm 0.58$ and $3.27 \pm 0.69 \log 10$ $\mathrm{cfu} / \mathrm{cm}^{2}$, in the samples taken from outlet band of water cooling tank were $2.74 \pm 0.82,1.47 \pm 1.35$ and $0.32 \pm 0.86$ $\log 10 \mathrm{cfu} / \mathrm{cm}^{2}$, respectively. Coliform bacteria number of the samples taken from end product band of diet department before sanitation and at the $20 \mathrm{~min}$ after sanitation process were $2.44 \pm 0.81$ and $1.65 \pm 1.43 \log 10$ $\mathrm{cfu} / \mathrm{cm}^{2}$, respectively, no coliform bacteria was detected at the $30 \mathrm{~min}$ after sanitation process. The prevalence of Salmonella spp. in the samples taken from defeathering machine fingers before sanitation and at the 20 and 30 minutes after sanitation process were $66.67 \%, 33.33 \%$ and $16.67 \%$, respectively. Salmonella spp. was detected in $8.33 \%$ of the samples taken from outlet band of water cooling tank and air cooling. Salmonella spp. was not detected in the samples taken from the end product band of diet department at any time.

Conclusion: As a result, it can be speculated that the cleaning and sanitation process implemented in the related establishment is satisfactory, however, extending shelf life of the products and eliminating the poultry meat-borne pathogenic microorganisms that threaten public health, performing better sanitation process may be recommended.

Key Words: Enterobacteriaceae, Salmonella spp., sanitation, slaughterhouse, poultry farkın önemli olduğu tespit edilmiștir $(p<0,05)$. Enterobacteriaceae sayısı sanitasyon öncesi ve sonrası 20. ile 30. dakikalarda tüy yolma parmağında sırasıyla; $4,00 \pm 2,09,2,43 \pm 0,58$ ve $3,27 \pm 0,69 \log 10 \mathrm{kob} / \mathrm{cm}^{2}$, su soğutma çıkıș bandında sırasıyla; $2,74 \pm 0,82,1,47 \pm 1,35$ ve $0,32 \pm 0,86 \log 10 \mathrm{kob} / \mathrm{cm}^{2}$ olarak tespit edildi. Diyet bölümü son ürün bandında sanitasyon öncesi ve sonrası 20. dakikada sırasıyla; $2,44 \pm 0,81,1,65 \pm 1,43 \log 10$ kob/ $\mathrm{cm}^{2}$ olarak saptanırken sanitasyon sonrası 30 . dakikada koliform grubu bakteriye rastlanmadı. Salmonella spp. prevalansı ise sanitasyon öncesi tüy yolma parmağında örneklerin \%66,67'sinde, sanitasyon sonrası 20. dakikada \%33,33'ünde ve 30. dakikada örneklerin \%16,67'sinde, sanitasyon öncesi su soğutma çıkıș ve hava soğutma çıkıș bantlarında örneklerin \%8,33'ünde Salmonella spp. tespit edildi. Diyet bölümü son ürün bandında ise hiçbir așamada Salmonella spp. varlığına rastlanmadı.

Sonuç: Sonuç olarak, daha iyi bir hijyenin sağlanması, üretilen ürünlerin daha uzun raf ömrüne sahip olması ve kanatlı eti kaynaklı halk sağlığını tehdit edici mikroorganizmaları elemine etmek için sanitasyonun daha etkili bir şekilde yapılması önerilebilir.

Anahtar Kelimeler: Enterobacteriaceae, Salmonella spp. kanatlı, kesimhane, sanitasyon

\section{INTRODUCTION}

Microbial contamination of chicken meat vary depending on various processes applied during production, slaughtering and processing $(1,2)$. In spite of slaughtering hygiene, contamination of poultry meat with microorganisms can not be completely prevented. Many factors influence the microflora of poultry meat. These factors include water, air, breeding conditions, transport, slaughterhouse process, packaging, and distribution conditions (3). Due to the factors effecting on poultry microflora, poultry and poultry meat can contain numerous and various microorganisms. Among these microorganisms, 
pathogenic bacteria such as Salmonella spp., Listeria monocytogenes, Bacillus cereus, Escherichia coli, Clostridium spp. may be present $(4,5)$. Many studies have shown that Salmonella spp., Campylobacter, Staphylococcus aureus and pathogenic Escherichia coli strains are the main responsible microorganisms of chicken meat-borne infections (6-9).

The only one possibility of extending the shelf life of fresh chicken meat and inactivating pathogenic microorganisms is the implementation of an appropriate hygiene and sanitation program during operation. For this purpose, a number of studies have been carried out on the sanitation applications at different stages of the slaughter process. It has been reported that the hygiene and sanitation processes which are applied according to the product flow chart in the slaughtering process can reduce or increase the level of microorganisms on the final products (10-12). The prevelance of Salmonella and Campylobacter are found to be increased in the carcasses, especially after carcass cooling process, and it was reported that this increase is caused by cross contamination (13). The disinfectants which are applied to prevent cross-contamination in many slaughterhouse differ, due to their application dose and effictiveness. It is emphasized that sanitization applications are applied at more than one point (defeathering, crop removal, inner-outer bird washing, pre-cooling) or only in the last stage of the slaughtering process in the forms of immersion (pre-cooling water) or spraying (air cooling) $(9,14)$.

There are many chemical substances which antimicrobial effects have been investigated, and their effectiveness have been compared in many studies $(6-8,11,15)$. The most commonly used chemicals are organic acids (13), trisodium phosphate (15), chlorinated disinfectants (11), acidified sodium chloride (6), acetic acid (9), and cetylpyridiniumchloride (16). The antimicrobial effect of the used chemical substances depends on disinfectant, concentration, $\mathrm{pH}$, temperature, application time and application method. Applied chemical substances generally have a capacity of reducing Salmonella spp. up to 2-3 $\log 10$ (9). Although there are many studies in the literature conducted on the microbial quality of poultry carcasses and carcass parts (17-22), there have been limited number of studies regarding the efficacy of disinfectant application on surfaces which have directly contact with the carcasses or carcass parts.

The present study was conducted to investigate the antimicrobial effect of the sanitation process, performed in a commercial slaughterhouse, on rubber fingers of mechanical defeathering machine, outlet band of water chilling tank, outlet band of air cooling band and the final product band.

\section{MATERIAL and METHOD}

\section{Cleaning and Disinfection Process Applied in Slaughterhouse}

The cleaning-disinfection operations in the slaughterhouse where the samples were taken, start with the physical cleaning using pressurized hot water at 50-60 ${ }^{\circ} \mathrm{C}$. Subsequently, detergent (alkaline foam cleaning product at minimum 2\% (v/v) concentration) is added to the system by automatic dispensing system and then foam application is performed. Afterwards, the brushing process is performed manually (minimum 20 minutes), and the cleaning step is completed by washing with hot water at $50-60{ }^{\circ} \mathrm{C}$. Disinfection is applied after the cleaning phase. For disinfection application, at least $0.2 \%$ $(\mathrm{v} / \mathrm{v})$ solution of a commercial disinfectant containing minimum $30 \%(\mathrm{v} / \mathrm{v})$ hydrogen peroxide solution, is prepared and applied to the defeathering machine by manually.

The disinfectant used for the outlet band of water chilling, outlet band of air cooling, and final product bands is prapered at minimum $2 \%(\mathrm{v} / \mathrm{v})$ concentration by using a commercial disinfictant including $\mathrm{C} 12$ - 
C14-alkyldimethyl (quaternary salt and amphoteric substance), disodium tetraborate decahydrate, betains, quaternary ammonium alkaloids, quaternary salt and amphoterine, N-(3-aminopropyl), dodecylpropane-1,3-diamine (amine functionalized biocidal amine effective against Gram negative and Gram positive bacteria), and applied. Approximately 45 minutes after the disinfection process, rinsing is carried out using pressurized hot water at 50-60 ${ }^{\circ} \mathrm{C}$. The qualitative residue control of disinfectants which are applied during slaughterhouse sanitation is carried out using test strips.

\section{Samples Collection}

Swab samples were collected from 4 different points including defeathering machine fingers (DF), water chilling outlet band (WC), air cooling outlet band (AC) and final product band (diet section) (DS) (before sanitation and at the 20 and 30 minutes after sanitation process). In a total 36 samples (4 sampling point $x 3$ samples for each sampling points $x 3$ sampling times) were collected in each sampling day, The study was repeated 4 times and a total of 144 swab samples were examined.

Samples were taken from $10 \times 10 \mathrm{~cm} 2$ area of the water chilling tank outlet band, air cooling outlet band and diet section by swab method. Swab samples of the mechanical defeathering machine were taken from the rubber fingers $(\sim 137 \mathrm{~cm} 2)$. Total number of mesophilic aerobic bacteria (TMAB), Enterobacteriaceae, coliform group bacteria counts, and Salmonella spp. prevalance were determined.

\section{Microbiological Analysis}

Plate Count Agar medium (PCA) (Merck, Darmstadt/ Germany) was used for total mesophilic aerobic bacteria counts, and petri plates incubated at $35{ }^{\circ} \mathrm{C}$ for 24-48 hours. Colonies were counted at the end of the incubation period (23). Violet Red Bile Dextrose Agar (VRBD) (Merck, Darmstadt/Germany) medium was used to detect count of Enterobacteriaceae. After the first layer of medium solidification, the second layer of VRBD was added to the petri plates and plates were incubated at $37{ }^{\circ} \mathrm{C}$ for 24 hours. At the end of the incubation period, colonies with a red color of 1-2 $\mathrm{mm}$ in diameter and a ring shape around them were evaluated as a suspect colony of Enterobacteriaceae. At least 5 of the suspected colonies were taken and tested for oxidase and then total numbers were determined (24). Violet Red Bile Agar (Merck, Darmstadt/Germany) medium was used for coliform bacteria counts and petri plates were incubated for 24 hours at $37{ }^{\circ} \mathrm{C}$. After the incubation period, all red colored colonies in petri dishes were counted as coliform bacteria (25).

Salmonella spp. samples were analyzed with the Mini Vidas at the slaughterhouse laboratory. For Salmonella spp. analysis the samples were taken with sterile sponges $(10 \times 10 \mathrm{~cm} 2$, sponges weight approximately $25 \mathrm{~g})$. Sponges were incubated at $41.5{ }^{\circ} \mathrm{C}$ for $18-24$ hours in $225 \mathrm{ml}$ buffered peptone water containing 1 $\mathrm{ml}$ Salmonella supplement (Biomerieux, France) for the pre-enrichment step. After the pre-enrichment step, $0.5 \mathrm{ml}$ of samples were added to the wells of the Vidas up Salmonella test kits and heated on the Vidas heat\&go for 5 minutes. Subsequently, the results were evaluated after 48 minutes. Manufacturer's guidelines were followed during Salmonella spp. analysis (BioMerieux, France).

\section{Statistical Analysis}

In this study, the microbiological data were converted to $\log 10 \mathrm{cfu} / \mathrm{cm} 2$ and statistical analyzes were performed. For this purpose, conformity to the assumption of normality from the prerequisites of the parametric tests was performed using the ShapiroWilk test and the homogeneity of the variances were checked with the Levene "test and then parametric tests were used. Analysis of variance (ANOVA) test was performed determine the differences between the groups and post-hoc Tukey test was used for comparisons of the groups. The Kruskall Wallis test was used for the analysis of variance of the groups with no normality assumption, and pairwise comparisons of the groups were evaluated with the Mann Whitney $U$ test. 
All statistical analyzes were performed using the SAS (Statistical Analysis System) package program (26). The statistical significance level was accepted as $p<0.05$.

\section{RESULTS}

\section{Total Mesophilic Aerobic Bacteria (TMAB) Results}

The TMAB counts on the defeathering machine fingers were $5.69,4.55$, and $4.64 \log 10 \mathrm{cfu} / \mathrm{cm} 2$ before sanitation, $20 \mathrm{~min}$ and $30 \mathrm{~min}$ after sanitation, respectively (Table 1). The differences between TMAB counts before, 20 and $30 \mathrm{~min}$ after sanitation were significant $(p<0.05)$. The differences in TMAB number before and after sanitation on the water chilling outlet band were not significant $(p>0.05)$. TMAB counts on air cooling outlet band were significant between before and 20 and $30 \mathrm{~min}$ after sanitation $(p<0.05)$. In the diet section, the difference between before sanitation and 20 minutes after sanitation was insignificant ( $p>0.05$ ), while the difference between before sanitation and 30 minutes after sanitation was significant $(p<0.05)$.

Before sanitation, the differences between the $T M A B$ counts of defeathering machine fingers and other sampling points were significant $(p<0.05)$. A significant difference was found between the water chilling and air cooling outlet bands, while there were not found any differences between the water chilling and air cooling outlet bands at 20 minutes after the sanitation $(p<0.05) .30$ min after sanitation, the TMAB numbers were $4.64 \log 10 \mathrm{cfu} / \mathrm{cm} 2$ in defeathering machine fingers, while the water chilling output, the air cooling output and the diet section final product bands were $0.47,0.19$, and $0.09 \log 10 \mathrm{cfu} /$ $\mathrm{cm} 2$, respectively. The differences between the defeathering stage and other sampling points were significant $(p<0.05)$.

\section{Enterobacteriaceae Results}

The difference between pre-sanitation and 20 min post-sanitary counts of Enterobacteriaceae was statistically significant $(p<0.05)$, while the difference between before sanitation and $30 \mathrm{~min}$ after sanitation was insignificant $(p>0.05)$. The difference between before sanitation, 20 and 30 min after sanitation in the water chilling outlet band was significant $(p<0.05)$. Enterobacteriaceae counts in the air cooling outlet band, before sanitation and 20 min after sanitation were $2.60,1.46 \log 10 \mathrm{cfu} / \mathrm{cm} 2$ respectively, while

Table 1. The mean numbers of total mesophilic aerobic bacteria of the swab samples $(\log 10 \mathrm{cfu} / \mathrm{cm} 2 \pm S D),(\mathrm{n}: 12)$

Sampling Time $(\mathrm{min})$

\begin{tabular}{|c|c|c|c|}
\hline $\begin{array}{c}\text { Sampling } \\
\text { Points }\end{array}$ & $\begin{array}{c}\text { Before } \\
\text { Sanitation }\end{array}$ & 20 min After Sanitation & 30 min After Sanitation \\
\hline DF & $5.69 \pm 0.83^{\mathrm{ax}}$ & $4.55 \pm 1.22^{\text {ay }}$ & $4.64 \pm 0.83^{\text {ay }}$ \\
\hline WC & $0.32 \pm 0.86^{c y}$ & $1.91 \pm 1.65^{\mathrm{bx}}$ & $0.47 \pm 0.93^{\text {by }}$ \\
\hline $\mathrm{AC}$ & $3.45 \pm 0.5^{\mathrm{bx}}$ & $1.52 \pm 1.64^{\text {by }}$ & $0.19 \pm 0.38^{\mathrm{bz}}$ \\
\hline DS & $3.03 \pm 0.4^{\mathrm{bx}}$ & $3.11 \pm 2.13^{\mathrm{abx}}$ & $0.09 \pm 0.31^{\text {by }}$ \\
\hline
\end{tabular}


Enterobacteriaceae was not detected 30 min after sanitation. The differences between before and after sanitation (20 and $30 \mathrm{~min}$ ) were significant $(\mathrm{p}<0.05)$. The differences between $20 \mathrm{~min}$ and $30 \mathrm{~min}$ after sanitation in diet section was significant $(p<0.05)$.

Although, Enterobacteriaceae counts differences between the defeathering machine fingers and water chilling output band were insignificant ( $p>0.05)$, it was found that the differences among the defeathering machine fingers and other sampling points were significant $(p<0.05)$. It was determined that the difference between sampling points $20 \mathrm{~min}$ after sanitation was not significant $(p>0.05)$ and 30 min difference between defathering machine fingers and other sampling points was significant $(p<0.05)$ (Table 2).

\section{Coliform Bacteria Results}

Coliform bacteria counts in the defeathering machine fingers were found as 4.16, 2.72, and $3.37 \log 10 \mathrm{cfu} / \mathrm{cm} 2$ before sanitation, $20 \mathrm{~min}$ after sanitation, and 30 min after sanitation, respectively. Coliform bacteria count differences between before sanitation and 20 min after sanitation on defeathering machine fingers were significant $(p<0.05)$. The differences among before sanitation, $20 \mathrm{~min}$, and 30 min after sanitation on the water chilling outlet band were significant $(p<0.05)$, while the differences on the air cooling outlet band were insignificant $(p>0.05)$. The difference between the before sanitation and 20 min after sanitation in the dietary section final product line was insignificant $(p>0.05)$. However, the difference between before sanitation and 30 min after sanitation was significant $(p<0.05)$. The differences among the defeathering step and other sampling points were significant before and 30 min after sanitation $(p<0.05)$ (Table 3$)$.

\section{Salmonella spp. Results}

While 30 min after sanitation Salmonella spp. was not found in the diet section outlet band and air chilling outlet band, Salmonella spp. prevalances before sanitation in defeathering machine fingers, water chilling outlet band and air cooling outlet band were found as $66.67 \%, 8.33 \%$ and $8.33 \%$, respectively. 20 min after sanitation, Salmonella spp. prevalence in defeathering machine fingers was found as $33.33 \%$, while on water chilling, air cooling and diet section were not detected. The prevalances of Salmonellaspp. in defeathering machine finger and water chilling outlet band 30 min after sanitation were found as $16.67 \%$ and $8.33 \%$, respectively. Salmonella spp. was not detected on the air cooling outlet band and the diet section (Table 4).

Table 2. The mean numbers of Enterobacteriaceae of the swab samples (log10 cfu/cm2 \pm SD), ( $\mathrm{n:} 12)$

\begin{tabular}{cccc}
\hline & \multicolumn{2}{c}{ Sampling Time (min) } \\
\hline $\begin{array}{c}\text { Sampling } \\
\text { Points }\end{array}$ & $\begin{array}{c}\text { Before } \\
\text { Sanitation }\end{array}$ & 20 min After Sanitation & 30 min After Sanitation \\
\hline DF & $4.00 \pm 2.09^{\mathrm{ax}}$ & $2.43 \pm 0.58^{\mathrm{ay}}$ & $3.27 \pm 0.69^{\mathrm{axy}}$ \\
WC & $2.74 \pm 0.82^{\mathrm{abx}}$ & $1.47 \pm 1.35^{\mathrm{ay}}$ & $0.32 \pm 0.86^{\mathrm{bz}}$ \\
AC & $2.60 \pm 0.49^{\mathrm{bx}}$ & $1.46 \pm 1.46^{\mathrm{ay}}$ & $0.00 \pm 0.00^{\mathrm{bz}}$ \\
DS & $2.57 \pm 0.86^{\mathrm{bx}}$ & $1.55 \pm 1.36^{\mathrm{ay}}$ & $0.00 \pm 0.00^{\mathrm{bz}}$ \\
\hline
\end{tabular}

ab: The numbers in the same column with the different letters are significantly different $(p<0.05)$.

$x y z$ : The numbers in the same row with the different letters are singinicantly different $(p<0.05)$.

DF: Defeathering machine fingers; WC: Water chilling outlet band; AC: Air chilling outlet band; DS: Diet section. 


\section{DISCUSSION}

This study was conducted to investigate the effectiveness of the sanitation (cleaning + disinfection) treatment applied in poultry slaughterhouses with the samples taken from steps with different levels of pollution, which can be the source for cross contamination in slaughterhouses. Although there are many studies on poultry meat, carcass parts and decontamination materials $(6-8,11,15,17-22)$, a very limited number of literature regarding effectiveness of sanitization are available. Results of these studies summarized below.
Rasschaert et al. (27) investigated the slaughtering process for Salmonella contamination in 3 different broiler slaughterhouses located in Belgium and applying the same production procedure. There had been analysed samples for Salmonella spp. which were taken one hour before the starting slaughter and a few hours after the cleaning-disinfection process from defeathering machine, which was selected as an important equipment for contamination, and it stated that the defeathering machine was risky for Salmonella spp. contamination. They detected Salmonella spp. in the first slaughterhouse, 24 samples were tested and 17

Table 3. The mean numbers of coliform bacteria of the swab samples $(\log 10 \mathrm{cfu} / \mathrm{cm} 2 \pm S D),(\mathrm{n}: 12)$

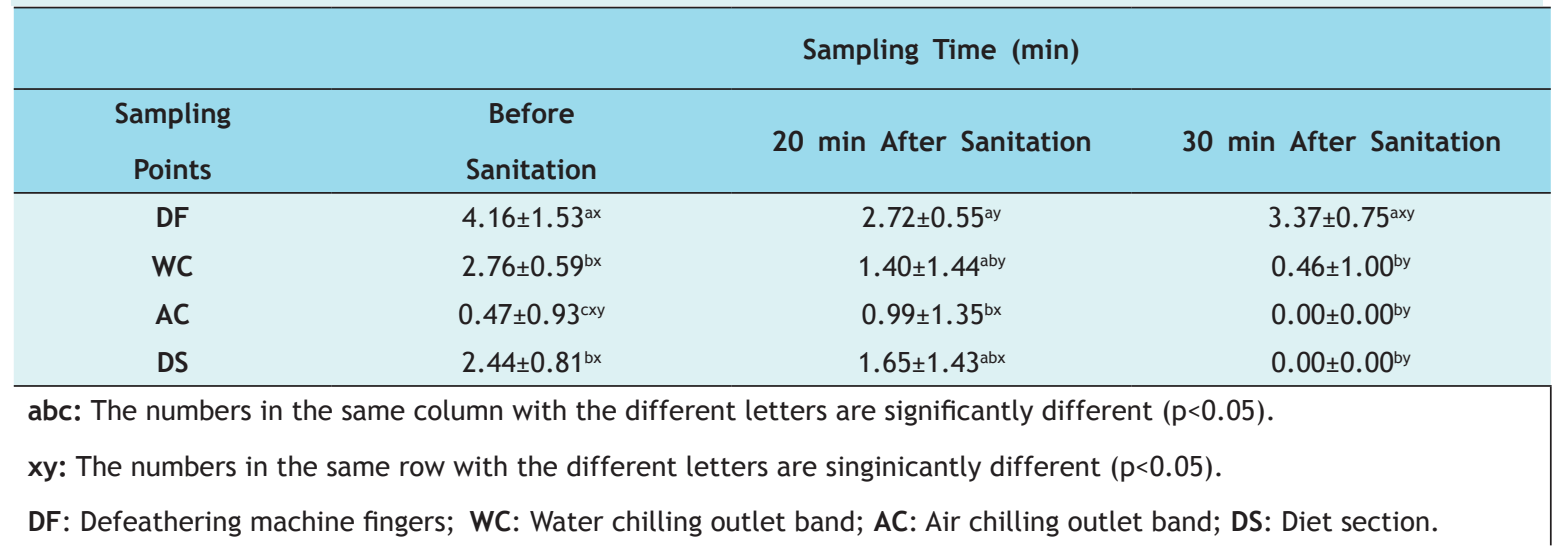

Table 4. Salmonella spp. prevalences of the swab samples (\%) (Positive samples/Total samples), ( $\mathrm{n}: 12$ )

\begin{tabular}{cccc}
\hline & \multicolumn{2}{c}{ Sampling Time (min) } \\
\hline Sampling & Before & 20 min After Sanitation & 30 min After Sanitation \\
Points & Sanitation & $33.33 \%(4 / 12)$ & $16.67 \%(2 / 12)$ \\
\hline DF & $66.67 \%(8 / 12)$ & $0.00 \%(0 / 12)$ & $8.33 \%(1 / 12)$ \\
WC & $8.33 \%(1 / 12)$ & $0.0 \% 0(0 / 12)$ & $0.00 \%(0 / 12)$ \\
AC & $8.33 \%(1 / 12)$ & $0.00 \%(0 / 12)$ & $0.00 \%(0 / 12)$ \\
DS & $0.00 \%(0 / 12)$ & & \\
\hline DF: Defeathering machine fingers; WC: Water chilling outlet band; AC: Air chilling outlet band; DS: Diet section.
\end{tabular}


(70.83\%) of them received from the clamps, conveyor belts and wheels of the defeathering machine, from the fingers and between the fingers were positive in means of Salmonella spp., in the 2nd slaughterhouse 12 samples were tested and 7 (58.3\%) of them taken from out of the bands among the conveyor belt, wheels and fingers were positive. Salmonella spp. was not detected in the samples taken from the third slaughterhouse. They emphasized that transport vessels and the slaughterhouse environment could also be contamination source for the final products. In our study, Salmonella spp. was detected in $66.7 \%$ of the samples taken from the defeathering machine in pre-sanitation stage.

In a study conducted in the poultry slaughterhouse in South Africa $7.7 \log 10 \mathrm{cfu} / \mathrm{cm} 2$ TMAB count was reported on the defeathering machine fingers (28). In this study, TAMB was found $5.69 \log 10 \mathrm{cfu} / \mathrm{cm} 2$ before the sanitation. The reason of the lower number of detected TMAB, because of the differences in the sampling methods between the studies, and the poultry slaughtered at different times also may have different microbial loads.

Geornaras et al. (28), was found the number of TMAB more than $6 \log 10 \mathrm{cfu} / 25 \mathrm{~cm} 2$ and the number of Enterobacteriaceae more than $4 \log 10 \mathrm{cfu} / 25 \mathrm{~cm} 2$ in swabs taken from a band in the packaging section. In our study, the TMAB numbers of the 2 different bands (air cooling and final product bands) in the packaging area of the slaughterhouse were 3.45 and $3.03 \log 10 \mathrm{cfu} / \mathrm{cm} 2$ respectively; while the number of Enterobacteriaceae were 2.60 and $2.57 \log 10 \mathrm{cfu} /$ $\mathrm{cm} 2$, respectively.

Arnold (29) determined the number of TMAB in the rubber fingers of three different slaughterhouse as $2.98 \log 10 \mathrm{cfu} / \mathrm{cm} 2$ for the first slaughterhouse, $3.70 \log 10 \mathrm{cfu} / \mathrm{cm} 2$ for the second slaughterhouse, and $5.57 \log 10 \mathrm{cfu} / \mathrm{cm} 2$ for the third slaughterhouse. In our study, number of total mesophilic aerobic bacteria were detected as $5.69 \log 10 \mathrm{cfu} / \mathrm{cm} 2$ at the defeathering machine finger. The number of total mesophilic bacteria that was found in the other two slaughterhouse by Arnold (29) were considerably lower than our findings, although there is a similarity between the TMAB count of the third slaughterhouse and the number of TMAB counts we found in our current study.

Abu-Ruwaida et al. (30) investigated the microbial contamination of equipment and containers in two different poultry slaughterhouse in Kuwait and found that in the first and second slaughterhouse of 10-20 $\mathrm{cm} 2$ of chicken pick-up band, one of the surfaces chosen from packaging area had 5.4 and $5.3 \log 10$ $T M A B$, respectively. In the present study, $3.45 \log 10$ $T M A B$ were detected in each $\mathrm{cm} 2$ in the swab result of pre-sanitation from the air-cooling outlet band. The reasons of the differences between these studies and our findings, may be the sampling method, the water temperature used in scalding, the chemical decontaminants added to the scalding water, the duration of scalding, the outer surface pollution ratings of the poultry, the amount of water entering the water chilling tanks, the type and amount of disinfectants used in the water chilling, the cleaning, disinfection, and hygiene program applied in the slaughtering process.

In this study, the number of microorganisms detected in samples that were taken at 20 and 30 min after sanitation in the same places were higher than the pre-sanitation values, this can be due to cracks, deformations or roughness of the fingers or finger surfaces where swabs were taken. Effective sanitation does not take place in these areas due to the fact that both sanitary and disinfectant substances can not sufficiently affect in these sites. There is no criteria for hygienic condition of tools and equipments in the Turkish Codex Alimentarius, Regulation on Microbiological Criteria Annex-2 In production hygiene criteria (31), there is only microbial criteria for broiler and turkey carcasses. However, in our study, it was determined that the Salmonella spp. prevalence reduced as passing from 
the dirty area to the clean area, and it was evaluated as a positive result that Salmonella spp. was not detected in the final product band.

In conclusion, microorganisms from the environment after the cleaning process can multiply rapidly in the food production enterprises and cause contamination in the next production. In addition to, some of the microorganisms during cleaning process can be removed by the water and spreaded to other surfaces. For this reason, a disinfection process must be performed after the cleaning process. The disinfection process, must completely destroy or reduce level of microorganisms that do not cause harmful effects. Equipment, tools, conveyor belts etc. used in operation should not be deformed, torn, cracked, rough or worn. Due to this, to change the defective, and problematic tools and equipments at the end of every working day or taking the necessary precautions by taking control of the slaugther line are very important for hygiene. Effective hygiene procedures are also essential for effective hygiene measures (including an effective hygiene program, appropriate water use, appropriate disinfectant selection and replacement at regular intervals, appropriate dosage, appropriate duration of effect, personnel training, etc.). In addition, it is extremely important for product hygiene that the necessary hygiene measures (an effective hygiene program, the appropriate use of water, appropriate disinfectant selection and replacement at regular intervals, appropriate dose, appropriate duration of effect, personnel training etc.) should be applied effectively.

\section{ACKNOWLEDGEMENT}

This study was summarized from the master's thesis and supported by the Firat University Scientific Research Projects Unit (Project number: VF.16.15).

\section{REFERENCES}

1. Buncic S, Sofos J. Interventions to control Salmonella contamination during poultry, cattle and pig slaughter. Food Res Int, 2012; 45(2):641-55.

2. Rajan K, Shi Z, Ricke SC. Current aspects of Salmonella contamination in the US poultry production chain and the potential application of risk strategies in understanding emerging hazards. Crit Rev Microbiol, 2017; 43(3):370-92.

3. Rouger A, Tresse 0 , Zagorec M. Bacterial contaminants of poultry meat: sources, species, and dynamics. Microorganisms, 2017; 5(3):50.

4. Chang YH. Prevalence of Salmonella spp. in poultry broilers and shell eggs in Korea. J Food Prot, 2000; 63(5):655-8.

5. Del Rio E, Panzio-Moran $M$, Prieto $M$, AlonsoCalleja C, Capita R. Effects of various chemical decontamination treatments on natural microflora and sensory characteristics of poultry. Int J Food Microbiol, 2007; 115(3):268-80.
6. Bolder NM. Decontamination of meat and poultry carcasses. Trends Food Sci Technol, 1997; 8(7):2217.

7. Dinçer $\mathrm{AH}$, Baysal T. Decontamination techniques of pathogen bacteria in meat and poultry. Crit Rev Microbiol, 2004; 30(3):197-204.

8. Ellerbroek L, Lienau JA, Alter T, Schlichting D. Effectiveness of different chemical decontamination methods on the Campylobacter load of poultry carcasses. Fleischwirtsch, 2007; 4:224-7.

9. Loretz M, Stephan R, Zweifel C. Antimicrobial activity of decontamination treatments for poultry carcasses: A literature survey. Food Control, 2010; 21:791-804.

10. Gonzalez-Fandos E, Dominguez JL. Effect of potassium sorbate washing on the growth of Listeria monocytogenes on fresh poultry. Food Control, 2007; 18:842-6. 
11. Northcutt J, Smith D, Ingram KD, Hinton AJ, Musgrove $M$. Recovery of bacteria from broiler carcasses after spray washing with acidified electrolyzed water or sodium hypochlorite solutions. Poult Sci, 2007; 86(10):2239-44.

12. Sinhamahapatra M, Biswas S, Das AK, Bhattacharyya D. Comparative study of different surface decontaminants on chicken quality. Br Poult Sci, 2004; 45(5):624-30.

13. Smulders FJ, Greer GG. Integrating microbial decontamination with organic acids in HACCP programmes for muscle foods: prospects and controversies. Int J Food Microbiol, 1998; 44(3):149-69.

14. Kim JW, Slavik MF. Cetylpyridinium chloride (CPC) treatment on poultry skin to reduce attached Salmonella. J Food Prot, 1996; 59(3):322-6.

15. Capita R, Alonso-Calleja C, del Camino GarcíaFernández M, Moreno B. Activity of trisodium phosphate compared with sodium hydroxide wash solutions against Listeria monocytogenes attached to chicken skin during refrigerated storage. Food Microbiol, 2002; 19(1):57-63.

16. Şener A, TemizA. Tavuk kesimhane ve ișletmelerinde kullanılan ticari dezenfektanlar ve etkinlikleri. Orlab On-Line Mikrobiyoloji Derg, 2004; 10:1-28.

17. Benli H, Sanchez-Plata MX, Ithak OI, Nunez De Gonzalez MT, Keeton JT. Evaluation of antimicrobial activities of sequential spray applications of decontamination treatments on chicken carcasses. Asian-Australas J Anim Sci, 2015; 28(3):405-10.

18. Escudore-Gilete ML, Gozalez-Miret ML, Hredia FJ. Multivariate study of the decontamination process as function of time, pressure and quantity of water used in washing stage after evisceration in poultry meat production. J Food Eng, 2005; 69(2):245-51.

19. James C, James SJ, Hannay N, Purnell G, BarbedoPinto C, Yaman H, Araujo M, et all. Decontamination of poultry carcasses using steam or hot water in combination with rapid cooling, chilling or freezing of carcass surfaces. Int J Food Microbiol, 2007; 114(2): 195-203.

20. Musavian HS, Krebs NH, Nonboe U, Corry JE, Purnell G. Combined steam and ultrasound treatment of broilers at slaughter: A promising intervention to significantly reduce numbers of naturally occurring Campylobacters on carcasses. Int J Food Microbiol, 2014; 176: 23-8.
21. İthak oi, İncili GK, Durmușoğlu H. Evaluation of effect of thymol combined with lactic acid or sodium lactate on psychrophilic bacteria and Salmonella spp. on chicken drumstick. Ann Anim Sci, 2017; 17(1): 271-80.

22. İthak Oi, İncili GK, Durmușoğlu H. Effect of some chemical decontaminants on the survival of Listeria monocytogenes and Salmonella Typhimurium with different attachment times on chicken drumstick and breast meat. J Food Sci Technol, 2018; 55(8):3093-7.

23. United States Department of Agriculture/ Food Safety and Inspection Service- USDA/FSIS: Microbiology Laboratory Guidebook. Metot 3.01, Quantitative analysis of bacteria in foods as sanitary indicators. 2011.

24. International Organization for Standardization (ISO) 21528-2:2004: Microbiology of food and animal feding stuffs-Horizontal methods for the detection and enumeration of Enterobacteriaceae-Part 2: Colony-count method.

25. International Organization for Standardization (ISO) 4832:2006 (E): Microbiology of food and animal feding stuffs-Horizontal method for the enumeration on coliforms-Colony-count technique. 2006.

26. Statistical Analysis System (SAS).Version 8.0. SAS Institute. Cary, North Caroline, USA. 1999.

27. Rasscahert G, Houf K, De Zutter L. Impact of the slaughter line contamination on the presence of Salmonella on broiler carcasses. J Appl Microbiol, 2007; 103:333-41.

28. Geornaras I, de Jesus A, Van Zyl E, von Holy A. Microbiological survey of South African poultry processing plant. J Basic Microbiol, 1995; 35(2):7382.

29. Arnold JW. Bacterial contamination on rubber picker fingers before, during and after processing. Poult Sci, 2007; 86(12):2671-5.

30. Abu-Ruwaida AS, Savaya WN, Dashti BH, Murad M, Al-Otman HA. Microbial quality of broilers during processing in a modern commercial slaughterhouse in Kuwait. J Food Prot, 1994; 57(10):887-92.

31. Turkish Codex Alimentarius: Turkish Codex Alimentarius, Regulation on Microbiological Criteria Annex-2, In production hygiene criteria Regulation No:28157, December 29, 2011, Ankara, Turkey. 